\title{
Reviewer Acknowledgements for Global Journal of Health Science, Vol. 8, No. 6
}

Global Journal of Health Science wishes to acknowledge the following individuals for their assistance with peer review of manuscripts for this issue. Their help and contributions in maintaining the quality of the journal are greatly appreciated.

Global Journal of Health Science is recruiting reviewers for the journal. If you are interested in becoming a reviewer, we welcome you to join us. Please find the application form and details at http://www.ccsenet.org/reviewer and e-mail the completed application form to gjhs@ccsenet.org.

\section{Reviewers for Volume 8, Number 6}

Abdollah Mahdavi

Aedan Olaso

Ama Pokuaa Fenny

Bashiru I.I. Saeed

Bruria Adini

Dilek Pirim

Evanthia Sakellari

Farahnaz Amini

Farshad Vakiki

Francisco Rodenas

Guangwu Li

Isac Silva de Jesus

Jan Chrastina

José Joaquín Mira

Kartheek R Balapala

Liu Liu

Loray Daws

Madhu Ouseph

Maria Malliarou

Matejka Rebolj
Meng Zhao

Nazisa Hejazi

Nishith H Vayada

Pelechas Eleftherios

Radu Spataru

Robert Sloan

Rod Duncan MacLeod

Rongfang $\mathrm{Hu}$

Sajjad Alavi

Samira Schultz Mansur

Shaillay Dogra

Shin-Young Lee

Snehal Padhye

Sondra L. Summers

Soon Soo Hoo

Srikrishna Sulgodu Ramachandra

Sultan Mosleh

Tracie Lee Pasold

Yan Ma

Zivana Gavric 